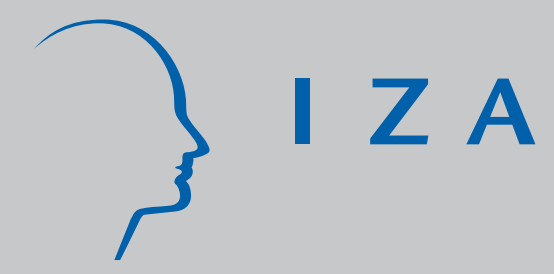

IZADP No. 3449

Determinants of Managerial Values on Corporate Social Responsibility: Evidence from China

Liangrong Zu

Lina Song

April 2008 


\title{
Determinants of Managerial Values on Corporate Social Responsibility: Evidence from China
}

\author{
Liangrong $\mathrm{Zu}$ \\ ITC/ILO \\ Lina Song \\ University of Nottingham \\ and IZA
}
Discussion Paper No. 3449
April 2008

IZA

P.O. Box 7240

53072 Bonn

Germany

Phone: +49-228-3894-0
Fax: +49-228-3894-180
E-mail: iza@iza.org

Any opinions expressed here are those of the author(s) and not those of IZA. Research published in this series may include views on policy, but the institute itself takes no institutional policy positions.

The Institute for the Study of Labor (IZA) in Bonn is a local and virtual international research center and a place of communication between science, politics and business. IZA is an independent nonprofit organization supported by Deutsche Post World Net. The center is associated with the University of Bonn and offers a stimulating research environment through its international network, workshops and conferences, data service, project support, research visits and doctoral program. IZA engages in (i) original and internationally competitive research in all fields of labor economics, (ii) development of policy concepts, and (iii) dissemination of research results and concepts to the interested public.

IZA Discussion Papers often represent preliminary work and are circulated to encourage discussion. Citation of such a paper should account for its provisional character. A revised version may be available directly from the author. 


\section{ABSTRACT \\ Determinants of Managerial Values on Corporate Social Responsibility: Evidence from China}

This paper empirically investigates how Chinese executives and managers perceive and interpret corporate social responsibility (CSR), to what extent firms' productive characteristics influence managers' attitudes towards their CSR rating, and whether their values in favour of CSR are positively correlated to firms' economic performance. Although a large proportion of respondents express a favourable view of CSR and a willingness to participate in socially responsible activities, we find that the true nature of their assertion is linked to entrepreneurs' instincts of gaining economic benefits. It is the poorly-performing firms, or rather, firms with vulnerable indicators - smaller in size, State-owned, producing traditional goods and located in poorer regions that are more likely to have managers who opt for a higher CSR rating. Managers' personal characteristics per se are not significant in determining their CSR choice. Moreover, controlling for other observed variables, we find that managers' CSR orientation is positively correlated with their firms' performance. The better-off a firm is, the more likely its manager is to get involve in CSR activities. Firms with better economic performance before their restructuring would sustain higher post-restructuring performance.

JEL Classification: M14, M21

Keywords: corporate social responsibility, profit maximisation, China

Corresponding author:

Lina Song

School of Sociology and Social Policy

University of Nottingham

Nottingham, NG7 2RD

United Kingdom

E-mail: lina.song@nottingham.ac.uk 


\section{Introduction}

Corporate social responsibility (CSR hereafter) has attracted a great deal of attention over the past decade. A large number of companies appear increasingly engaged in a serious effort to define and integrate CSR into all aspects of their businesses. Corporate executives have also encountered demands from multiple stakeholder groups to devote resources to CSR. This may be partially due to the presure generated by a union of ethics-oriented campaigners including NGOs, anti-capitalism activists, labour unions, and news media; and partially due to the demand for doing so by their customers, employees, suppliers, communities, governments, and even stockholders.

Corporate social responsibility and corporate citizenship has been introduced to China only in recent years. The introduction is driven by both external and internal factors. Externally, particularly after China's entry into the World Trade Organization, more multinational corporations have expanded their businesses in China. The resulting rise in trade, increased requirements for good quality products and services, and attention attracted by trading with China has caused a tension between business practices based on profit-maximising and anticapitalist campaigns promoting operational standards, best business practices, western values and moral standards. This conflict has induced to a response by Chinese firms.

Internally, in responding to the external demand for good practice, more Chinese corporate managers served as agents of change, promoting socially responsible business behaviour in China. Historically, the inseparable relationship between the State and its firms before economic reforms generated important social roles for the State-owned firms. Chinese enterprises, especially in the State sector, always had a tradition of taking social responsibility for their employees by providing safety nets and social protection through its work-unit system known as danwei (Li and Wang, 1996). The Danwei system collapsed since economic reform. As a result the social roles Chinese enterprises used to play have withered. Rapidly increased economic freedom and individual wealth have undermined old socialistic values. However, China remains an avowedly socialistic regime, and its economic policymaking is still set by the Central Committee of the Communist Party. On the one hand, firms' attention is switched to pure economic gain, so that balancing profits with social protection is becoming less important. On the other hand, the managers in the state sector are appointed by the Communist Party, and State-owned firms' economic decisions can still be interfered by 
the Party leaders at firm level. After all, however, these appointed firm managers are, by and large, the Communist Party members. They would naturally share their ideology with the State in favour of the communist tradition. For them, the external fashion defined as corporate socially responsibility (CSR) might just match the remnants of their socialistic beliefs.

There are, therefore, different dimensions and hence possible consequences linked to the debate. First, whether firms in a competitive market mechanism should be encouraged to pursue profit and view profitability as the primary overriding goal? Some argued that the danwei model failed as it damaged economic incentives and hence efficiency (Byrd, 1992; Knight and Song, 1999, Ch 1; 2005, Ch 2). How far could Chinese state-owned firms afford to reverse the current reform program and ditch rapid economic growth by reinstating its firm-based welfare model?

Second, if managers of firms follow market rules driven by "the invisible hand" (Adam Smith, 1776), should they still be guided by professional morality and become more involved in social responsibility? Obeying rules to create more sustainable market circumstances is not necessarily an invention of CSR. However, State agents (especially local governments) in China have retained a strong tendency to levy extra fees on firms in the name of "local community development" (Song, 1990; Song and Du, 1990), despite discouragement from the Central Government which aims to free firms from social burdens. Given these conditions - an incomplete market system in China; crucial resources still allocated by State agents; absent safety-nets for the majority of Chinese; and State control still remaining strong - could CSR activities become another form of government intervention in market formation distorting firms' economic behaviours?

Thirdly, industrial values reflecting the phenomenon of money-worship - an over-stressing of material interests - despite having accompanied the long process of industrialisation for most developed nations, could also be framed by laws, regulations and social morals. In fact, there are fewer cases of maximising profit by compromising social goals reported in the so-called capitalist countries than in China. Under increasing pressure from market competition, Chinese enterprises may pay too much attention to economic gains and insufficiently balance profits and moral standards. The paradoxical phenomenon is whether, and how, profitmaximisation would compromise or assist socially responsible activities; would managers' 
higher standards of integrity and ethics lead to more corporate responsibility?

To answer these questions, we use a questionnaire survey purposively designed by the authors. The survey was conducted within a one-year period between 2003 and 2004. 100 Chinese industrial enterprises and their chief executives were contacted. The sample was designed to cover all regions, ownership type and industrial sectors in China. 83 firms responded to our request by providing valid information for the analysis. Questionnaires were designed with information drawn from sources of CSR literature, SOE reforms, industry and government studies and surveys of ownership restructuring.

The paper is organised as follows. Section 2 of this paper provides the analytical framework. Section 3 establishes evidence showing how Chinese managers perceive CSR activities and how their firms are actually involved in such activities. Section 4 conducts factor analysis by extracting principal components from managers' perceptions of CSR, and conceptualises the true nature of their perceptions. Section 5 examines the determinants of managers' CSR true ratings. Section 6 links firms' economic performance to their CSR behaviour. Section 7 presents our conclusions.

2. Analytical framework: managers' perceptions towards CSR versus firms' CSR activities

In management literature there has been growing interest in investigating the perceptions of top management toward CSR and the actions they may take regarding socially responsible issues. Keith Davis has laid the foundation and benchmark for the researchers to assess attitudes of managers toward CSR (Davis 1973, 312-23). He asserts the important arguments relating to the case for and against business social responsibility. Researchers have incorporated the same arguments in their studies, aiming at measuring managerial attitudes toward social responsibility (Rashid and Ibrahim 2002, 10-6; Quazi and O'Brien 2000, 33-51; Ostlund 1977, 35-49; Orpen 1987, 89-96; Ford and McLaughlin 1984, 666-74). However, the attitude-behaviour theory claims that the attitudes and intentions of top management, central to the strategy process of a firm, would be likely affected by the characteristics of their firms. Wood (1991, 758-69) underscores managerial intentions as the motivators of socially responsible behaviour, and stresses the management of stakeholder expectations as an 
integral part of the process. An assessment of a manager's attitudes toward to CSR, then, may provide an indication of the manager's inclination to respond in a particular way to CSR.

Little has been done in exploring the connections between managers' attitudes or their behaviours and the productive characteristics of their corporate activity in China: whether their political affiliation, their firms' ownership, industrial sector, scale of firms and other productive features would be correlated to their attitudes towards CSR. This paper, built on the attitudes-behaviours theory, presents an empirical study of how the managers perceive CSR in the context of China's economic reform. It examines what factors influence managers' attitudes toward CSR and particularly the relationship between managers' attitudes and their behaviours in restructuring: whether managers who are more socially responsible tend to undertake restructuring in a more socially responsible manner, and whether their social responsible behaviour is correlated to their firms' economic performance. To achieve this, the research, first, extracts the true nature of their attitudes towards CSR, and then turns to examine the determinants of their CSR ratings, finally to establish the relationship between their CSR rating and their firms' economic performances. The three empirically designed exercises provide insight into the extent to which CSR has been developed and interpreted in China. This is to ask: what the true nature of Chinese firm managers' attitudes towards CSR is; what factors have determined their CSR ratings and, finally whether their attitudes in favour of CSR would have impacts on their firms' economic performance, or vice versa.

\section{Basic information on the surveyed firms}

Table 1 shows the summary information of the sampled firms. $41 \%$ of sampled forms are from North China, $36 \%$ from South-east China and $23 \%$ from West China. Over $84 \%$ of the sample is state-owned enterprises, and more than $96 \%$ is large and medium-sized. The resulting data also shows that the sample covers seven industries, mainly focussed on manufacturing industry such as metal and machinery (47\%), and automobile manufacturing $(16 \%)$.

Managers were asked about their perceptions towards socially responsible behaviours, particularly what they think are most important CSR behaviours. From the statements in Table 2, we have given out a list of statements: some of them are more business-oriented, others more ethically-natured. We mix them up in order to find out how managers interpret 
CSR and the nature of their perceptions in terms of interpreting CSR behaviours. The behaviours most significantly identified by the managers (on the top list of their first choice) are "obeying laws" (72\%) and "producing good quality of products and services" (68\%). At the bottom of the list, "treating business partners with integrity" (46\%) and "participating in community work" (24\%) are identified. Obviously their interpretations of CSR behaviours are still traditionally highly dominated by the basic firm conduct codes, and the input of a CSR nature is rather limited.

Since the managers attached great importance to CSR, what socially responsible activities have the Chinese firms been involved in? Table 3 provides such information. Over the past 3 years, the firms had actually increased their employee welfare (98.8\%), paid tax to an honest level (97.6\%), obeyed regulation for environment protection and pollution control (97.6\%), had some involvements promoting public goods (86.6\%), contributed to assisting with vulnerable groups (82.9\%), made donations to cultural and educational events $(62.2 \%)$ and lastly, donated to charitable organizations (42.7\%). Judging from this list with the percentage revealing their involvement, we realise there is a limited entry to corporate philanthropic responsibility (donation and contribution without direct economic returns, or obvious impact on their public images). It seems that Chinese executives and managers do not perceive philanthropy as one of the important CSR activities.

This also corresponds to the current project launched by China's Enterprise Association (CEA). Interview results show that the managers of many large Chinese enterprises praise CSR but interpret it in many different ways. The most common belief behind their words is that firms should first obey the laws, pursue for economic gains and only after that do good things if they could afford to. CSR may help them attract publicity or gain social capital indirectly helping them with long-term economic gains ( $\mathrm{Li}, 2007)$. Now, we turn to empirically investigate the true nature of managers' perceptions towards CSR in our following exercises.

\section{Factor analysis: true motivations towards CSR}

In the survey managers were asked to address their attitudes for or against CSR, and their perceptions towards socially responsible restructuring. The questions concerned are given a 
five-point interval scale which ranges from (5) denoting "strongly agree" to (1) denoting "strongly disagree". In order to conceptualise the true motivation of corporate social responsibilities we have designed the following statements and have used them to identify CEO's attitudes towards CSR:

(1) Engaging in socially responsible actions does not compromise the pursuit of profit.

(2) To obtain a favourable public image can be achieved by showing involved in socially responsible activties.

(3) A socially responsible business could avoid additional regulations imposed by the government, and good relationship with the government would gain firms more freedom from all sorts of restrictions.

(4) Contributing to community's program and improve local development would bring in firms' long run profitability.

(5) Firms perceived as being socially responsible can improve industry-labour relations.

(6) Socially responsible activities could improve a firm's standing with banks and help them to gain easy access to bank loans.

(7) Socially responsible activities could improve a firm's standing with investors.

(8) Businesses have already had too much of a burden with societal affairs and they should not get involved in more social activities.

(9) There is no difference between involvement in socially responsible activities and positioning for public relations.

(10) Too much social responsibility could disadvantage firms economically.

(11) Business would be more willing to take on socially responsible activities when they are economically more sustainable.

We have received some mixed information on managers' interpretation of CSR (Tables 2 and 3). Yet we would need to identify the true factors behind their perceptions. Factor analysis with principal component extraction is employed to distinguish them. This may eventually provide us with a clearly-cut line, with which we could underline whether managers are truly for or against CSR, beyond their assertive arguments. We assume the motivation could be distinguished as (1) truly and genuinely believe in CSR; (2) using positive attitudes towards CSR to attract better public image and good social capital, and hence to attract more economic resources or avoid administrative penalties; (3) to simply dismiss CSR activities as they would damage firms' economic performance. 
Table 4 shows the simple distribution of managers' responses towards the statements. The statements later on will be employed to extract principal components revealing the true motivation of managers' attitudes towards CSR. From this table, actual distributions of percentage responses do not form particular patterns. Results of factor analysis are shown in Table 5. Three interesting components are clearly identified:

(1) The first component is most highly correlated among three statements: "positioning firms with CSR in order to avoid additional regulations composed by the government" (factor loading .750), "attracting bankers" (.690) and "attracting investors" (.803). This factor is apparently representing firms' economic incentives to use CSR for their economic gains.

(2)The second component is most highly correlated among public image (.595), "firms' contribution to community activities" (.801) and "CSR activities to lower industrial (capitallabour) conflicts" (.793). The second factor is typical of the pursuit of social capital via gaining a good public image.

(3) The third component is most highly correlated among "CSR improves profit-making" (.718), "long-run economic performance" (.718) and "too much social burden" (.651),. This factor reinforces factor one but more more starkly reveals the role of economic pursuits.

None of these factors extracted from the perceptions represents a strong favouring of CSR. In contrast, two important factors stand out: using CSR for better economic constituency and engaging in CSR activities to gain social-capital or a good public image as an indirect pursuit of long-run economic gains.

Table 6 presents the factor loading, means and weighted scores from which further explanation of factor analysis would be explored. Factor 1 reveals managers' perceptions of necessary constituency for their economic gains. The mean value of Factor 1 (3.29) does support our arugument. There are three important agents standing as their constituency: the government, banks and investors. In particular, the managers have ranked the relationship with government as the most important factor (3.59). It is argued that if business is more socially responsible, it will avoid additional regulation of the economic system by government, and reduce restrictions in firm's operations. This is in conformity with modern stakeholder theory (Cornell and Shapiro 1987, 5-14), which contends that the value of a firm 
depends on the cost not only of explicit claims but also of implicit claims. If a firm does not act in a socially responsible manner, parties to implicit contracts concerning the social responsibility of the firm may attempt to transform those implicit agreements into explicit agreements that will be more costly to it. For example, if a firm fails to meet promises to government officials in regard to actions that affect the environment (dumping, etc.) government agencies may find it necessary to pass more stringent regulations, constituting explicit contracts, to force the firm to act in a socially responsible manner. Moreover, socially irresponsible actions may spill over to other implicit stakeholders, who may doubt whether the firm would honour their claims. Thus, firms with an image of high CSR may find that they have more low-cost implicit claims than other firms and thus have higher financial performance (Cornell and Shapiro 1987).

The statistical analysis also indicates that CSR can create social capital (e.g. to improve public image, communities and industrial relations) for firms to grow. The mean value of Factor 2 (3.93) concerning CSR and business environment indicates that a firm with high CSR can capture a favourable public image, which is closely associated with firm's long-term self-interest, and may gain more customers, better employees and other benefits; and face relatively few employment conflicts. The result of analysis shows that respondents contend that a business that wishes to capture a favourable public image will have to show that it is socially responsible (4.34); involvement by business in improving its local community's quality life also improves long-term profitability (3.84); and a firm perceived as highly socially responsible can face a relatively low level of industrial issues (3.60).

The questions in the survey examining managers' attitudes toward the relationship between CSR and profitability were: whether the exercise of CSR is inconsistent with the profitability; and whether business participates more actively in social responsibility in prosperous economic times than in recession. In response to the first positive statement, the mean value (3.49) in Table 4 shows that managers are agreed that CSR is consistent with pursuit of profits. This proves the theory of social capital - spending resources for social programmes might actually result in more profit for the business. However, there is a small proportion of CEOs expressing explicitly that businesses' function is to maximize profits, and firms should concentrate on economic performance. This argument is in line with the classical economic doctrine of profit maximization, which argues that economic values are the sole criteria used to measure success. The manager is the agent of the stockholders, and all of his decisions are 
controlled by his desire to maximize profits for them. Responding to the second negative argument, the mean value (1.95) reveals that managers don't agree that businesses will actively participate in socially responsible activities only in prosperous economic times, not in recession. This implies that being a socially responsible firm should assume the social responsibility at any time.

In terms of the relationship between CSR and Public Relations, the means (3.33) shows that respondents agreed that there is difference between CSR and public relations positioning. The low mean value also indicates that some of the respondents regard CSR as a kind of public relations. Obviously, there was a slight difference between the two groups; this indicates that most Chinese managers do not have a clear idea of what CSR is, and what public relations positioning is. The three fundamental principles could be used to distinguish the two concepts. The first is to judge whether the socially responsible activities contribute to social benefits, second is whether socially responsible activities include much substance of a business.

When the overall scores of each respondent are added up, the ratings of CSR on the basis of their scores are developed. The result of the rating - $41 \%$ against and 59\% in favour of CSR - will be used for our further analysis. The dividing of the rating has resulted from our principal component extraction analysis, and they should be truly representing managers' attitudes towards CSR.

\section{Logit regression: determinants of managers' valuation of CSR}

To properly investigate the determinants of managers' CSR rating, we employ a binary logit model to explain its determinants, testing whether firms' productive features would have any impacts on managers' CSR choice. Our explained variable - managers' CSR rating generated from factor analysis - is of two values: $0=$ those who have obtained low values of CSR scores; and 1 = those whose CSR scores are high. Our explanatory variables are the characteristics of their firms, and of themselves. We model whether a manager's CSR rating $i$ is valued high $\left(R_{i}=1\right)$ or not $\left(R_{i}=0\right)$ :

$$
R^{*}{ }_{i}=\alpha^{\prime} X_{\mathrm{i}}+U_{\mathrm{i}} \quad \text { where } U_{\mathrm{i}} \sim N(0,1)
$$




$$
\operatorname{Pr}\left(\mathrm{R}_{\mathrm{i}}=1\right)=\operatorname{Pr}\left(\mathrm{R}_{\mathrm{i}}>0\right)=\Phi\left(\alpha^{\prime} X_{\mathrm{i}}\right)
$$

where $X_{\mathrm{i}}$ is a vector of explanatory variables and $\alpha$ a vector of associated coefficients. Among the explanatory variables are

(1) Firm's economic performance before CSR restructuring - logged total sales

(2) Firms' ownership - whether owned by the State

(3) Firms' industrial sector - whether they produce modern products

(4) Firms' size in terms of number of employees

(5) Firms' location

(6) Managers' age and education (both in years)

Table 6 provides the results of logit regression. Two models are presented in the table. The second model differs from the first model only by adding as an explanatory variable, the firms' annual sales before they took on restructuring towards CSR. It therefore provides a test of whether CSR choice is a result of firms' poor prior economic performance.

The first model confirms that managers' personal characteristics (age and education) are not statistically significant in determining their CSR choice when their firms' productive characteristics are controlled in the model. From the same model, State-owned firms are less likely to have managers who reject CSR in comparison with the non-state-owned firms (the ratio of the two odds is 0.28 ). This is also true for the firms in the poorer North-west provinces in comparison with those from South-east provinces (odds ratio is 0.39). Firms of large size are more likely to have managers of lower CSR ratings than smaller or medium sized firms (odds ratio is 1.9). The most revealing finding from this model is, controlling for other variables, modern industrial sectors (not in mining, traditional machinery, traditional manufacturing) are 5.6 times more likely to have managers who have low CSR scores than are firms in the traditional industrial sectors.

In model 2, we have added the total annual sales before firms' CSR restructuring with all other explanatory variables remaining the same in Model 1 . The marginal effect of the sales variable is negative although very small (less than $0.1 \%$ ), and not statistically significant. It is 
likely that the value on sales variable is diminished by the controls for other productive features of firms in the model.

In summary, we find from this exercise that firms in smaller or medium size State firms, producing traditional products and located in poorer regions are more likely to have managers retaining a higher CSR rating. On the other hand, firms providing modern products and services would be more likely to have managers retaining high CSR values.

5. Do managers' CSR values affect their firms' performance?

In this section, we investigate whether managers' CSR ratings is positively correlated on firms' pro-restructuring performance, measured in terms of sales. As with most nonexperimental data, we cannot be sure any relation we find is causal. However, correlations may be suggestive particularly given the finding in the previous section that manager's valuation of CSR is not affected by the firm's prior performance. We estimate two models, which differ only in whether the sales of firms prior to restructuring are include as one of the explanatory variables. This lagged dependent variable will capture some omitted determinants of sales and dynamic effects, but may also cause the coefficients on other included variables to be understated relative to their long run effects.

We employ OLS regression models to estimate sales functions of the form:

$$
S 2_{i}=a+b_{1} \ln \left(S 1_{i}\right)+b_{2} R_{i}+b_{3} O W_{i}+b_{4} \text { Size }_{i}+b_{5} S e c+b_{6} \text { Rro }+X_{i}+e_{i}
$$

where

$$
\begin{aligned}
& S 2_{i}=\log \text { (firms' post-restructuring annual sales) } \\
& S 1_{i}=\log \text { (firms' pre-restructuring annual sales) } \\
& R=\text { Indicator of managers' CSR rating; } 0=\text { lower rate; } 1=\text { higher rate } \\
& O W=\text { Firms' ownership; } 0=\text { non-State-owned, } 1=\text { State-owned } \\
& S i z e=\text { Firms' size; } 0=\text { smaller or medium, } 1=\text { large } \\
& S e c=\text { Firms' industrial sector; } 0=\text { traditional sector; } 1=\text { modern sector }
\end{aligned}
$$


Pro $=$ Firms' location; $0=$ South-east provinces; $1=$ north-west provinces

$X=$ vector of other controlled variables

$e=$ error term

and $a$, and $b$ are parameters.

Table 8 presents the results from this exercise. Without controlling for "the sales before restructuring", the only coefficient statistically significant is "firms' location" (Model 1). By including "the sales before restructuring" as an explanatory variable, we have more precisely estimated results (see Model 2).

The elasticity of post-restructuring sales with respect to pre-restructuring sales is 0.9. This implies that if sales were $100 \%$ higher before restructuring, they would be $90 \%$ higher after restructuring. There is therefore a large degree of persistence in the level of sales. Compared with managers of lower CSR rating, managers in favour of CSR have 86\% higher prerestructuring sales, controlling for other variables. This appears to be a very large impact on firms' economic performance although as previously stated we cannot be sure that this multivariate correlation is causal.

The other variables appear to have a variety of significant effects, ceteris paribus. State-owned firms have more than double the post-restructuring sales than non-State-owned firms (coefficient on this is 1.13 , significant at the $10 \%$ level). Managers whose educational level is above university degree have $155 \%$ higher post-restructuring sales than their counterparts whose educational level was lower. However managers' age has a negative effect on their firms' total sales. Managers older than 56 years have post-restructuring sales $104 \%$ lower than those who are younger.

\section{Conclusion}

In this paper, in order to explore the true nature of managers' perceptions towards corporate social responsibility (CSR), the determinants of their CSR rating and whether or not their CSR orientation would have a positive correlation with their firms' performance, we have conducted three main empirical exercises. First we employed factor analysis to extract the 
principal components from managers' perceptions towards CSR. We find that managers' assertions in favour of CSR could be misled by their confusion when interpreting the concepts. The true nature of their willingness to take on CSR activities could be more business-oriented than morally-led. CSR activities may be perceived as serving firms' economic aims whether directly or indirectly.

This has led us to explore what have indeed determined managers' CSR orientation. Via binary logit modelling on managers' CSR true rating (generated from previous factor analysis) we find that firm' productive features, rather than managers' personal characteristics, play more of a role. Firms with arguably poorer indicators of economic performance are more likely to have managers with high CSR values. For instance, firms of smaller size, producing traditional goods or services, owned by the State, and located in the poorer regions would be more likely to have managers who value CSR more.

Finally, we have examined whether the difference in managers' CSR value would affect firms' post-restructuring sales. Compared with those who have lower CSR orientations, managers with higher CSR values would increase their firms' total sale (after restructuring) by almost $90 \%$, ceteris paribus. However, in both of our regression exercises, we cannot be wholly confident that our explanatory variables have causal impacts due to the data limitations.

The concept of "corporate social responsibility" (CSR) has been around the business world for quite a while. It has been conceptualised as running against traditional business values of maximising economic gains. Like a fashion, many firms world-wide seem to welcome this concept. However we learn from this Chinese enterprise survey that the true determination of CSR orientation is still firms' economic features and, managers' interpretations of CSR activities could be seen in terms of economic incentives. Moreover, acceptance of CSR appears to do no harm to economic performance and indeed is associated with a large increase in sales. The better-off a firm is, the more likely its manager is to get involve in CSR activities. Firms with better economic performance before their restructuring would sustain higher post-restructuring performance.

The multi-dimensional concept of 'socialist market system' has created institutional contradictions for China's business environment. This makes firm management lacking 
consistency, and hence managers' strategy towards CSR could be modified and justified in order to suit their socio-political goals and their economic needs. 


\section{References}

Ajzen, I and M. Fishbein. 1977. "Attitude-Behavior Relations: A Theoretical Analysis and Review of Empirical Research." Psychological Bulletin 84888-918.

Ansoff, H. Igor. 1984. Implanting Strategic Management. Prentice Hall.

Aupperle, Kenneth. 1991. The Use of Forced-Choice Survey Procedures in Assessing Corporate Social Orientation. In Research in Corporate Social Performance and Policy. Ed. J.E.Post. Greenwich: C.T. JAI Press.

Aupperle, Kenneth E., Archie B. Carroll, and John D. Hatfield. 1985. "An Empirical Examination of the Relationship between Corporate Social Responsibility and Profitability." Academy of Management Journal 28446.

Barnard, Chester Irving. 1968. The Functions of the Executive. Harvard University Press.

Byrd, William A. 1992. Chinese Industrial Firms under Reform. Oxford University Press

Clarkson, Max E. 1991. Defining, Evaluating, and Managing Corporate Social Performance: The Stakeholder Management Model. In Research in Corporate Social Performance and Policy. Ed. J.E.Post. Greenwich: C.T. JAI Press.

Cornell, Bradford and Shapiro. Alan C. 1987. "Corporate Stakeholders and Corporate Finance." Financial Management 165-14.

Davis, Keith. 1973. "The Case for and Against Business Assumption of Social Responsibility." Academy of Management Journal 16312-23.

Ford, Robert and Frank McLaughlin. 1984. "Perceptions of Socially Responsible Activities and Attitudes: A Comparison of Business School Deans and Corporate Chief Executives." Academy of Management Journal 27666-74.

Freeman, R. Edward. 1984. Strategic Management: A Stakeholder Approach. Boston: Pitman.

Gill, Roger W. T. and Lisa J. Leinbach. 1983. "Corporate Social Responsibility in Hong Kong." California Management Review 25107-23.

Holmes, Sandra L. 1976. "Executive Perceptions of Corporate Social Responsibility." Business Horizons 1934-40.

Katz, D. 1960. "The Functional Approach to the Study of Attitudes." Public Opinion Quarterly 24163-204.

Knight, John and Song, Lina (1999), The Rural-Urban Divide, Economic Disparities and Interactions in China, New York and Oxford: Oxford University Press 
Knight, John and Song, Lina. 2005 Towards a Labour Market in China, New York and Oxford : Oxford University Press

Lerner, Linda D. and Gerald E. Fryxell. 1994. "CEO Stakeholder Attitudes and Corporate Social Activity in the Fortune 500." Business \& Society 3358-81.

Li, Lan (2007) "How the Chinese Entrepreneurs perceive Social Responsibility - 2007 Report on the Growth and Development of Chinese Entrepreneurs" edited by China Entrepreneurs Survey System, published by China Machine Press.

Li, Hanlin and Wang, Qi. 1996. Research on the Chinese work unit society. Frankfurt/Main and New York: Peter Lang Pub lnc

Maignan, Isabelle and O. C. Ferrell. 2003. "Nature of corporate responsibilities: Perspectives from American, French, and German consumers." Journal of Business Research 5655-67.

McGuire, Jean B., Alison Sundgren, and Thomas Schneeweis. 1988. "Corporate Social Responsibility and Firm Financial Performance." Academy of Management Journal 31854-72.

Orpen, Christopher. 1987. "The Attitudes of United States and South African Managers to Corporate Social Responsibility." Journal of Business Ethics 689-96.

Ostlund, Lyman E. 1977. "Attitudes of Managers toward Corporate Social Responsibility." California Management Review 1935-49.

Post, James E., Anne T. Lawrence, and James Weber. 2001. Business and Society: Corporate Strategy, Public Policy and Ethics. Mcgraw-Hill College.

Preston, Lee E. 1978. Comparing Corporate Social Performance and Policy: A Synthetic Framework for Research and Analysis. In Research in Corporate Social Performance and Policy. Greenwich, CT: JA.

Quazi, A. M. and D. O'Brien. 2000. "An Empirical Test of a Cross-national Model of Corporate Social Responsibility." Journal of Business Ethics 2533-51.

Rashid, Md Zabid Abdul and Saadiatul Ibrahim. 2002. "Executive and Management Attitudes towards Corporate Social Responsibility." Corporate Governance 210-6.

Song, Lina and Du, He (1990), "The Role of China 's Township Governments in Rural Industrialisation" in W. Byrd and Lin Qingsong (eds.), China 's Rural Industry, Oxford University Press

Song, Lina (1990), "Convergence: a Comparison between China 's State Enterprises and Rural Government-Owned Enterprises", in Byrd and Lin (eds.), China 's Rural Industry, World Bank/ Oxford University Press 
Smith, Adam. 1776. An Inquiry into the Nature and Causes of the Wealth of Nations. http://www.adamsmith.org/smith/won-index.htm

Teoh, Hai-Yap and Gregory Thong. 1984. "Another look at corporate social responsibility and reporting: An empirical study in a developing country." Accounting, Organizations and Society 9189-206.

Wokutch, R. E. and E. W. McKinney. 1991. Behavioural and Perceptual Measures of Corporate Social Performance. In Research in Corporate Social Performance and Policy. Ed. J.E.Post. Greenwich: C.T. JAI Press.

Wood, Donna J. 1991. "Corporate Social Performance Revisited." Academy of Management Review 16758-69.

Wood, Donna J. and E. J. Jone. 1995. "Stakeholder Mismatching: A Theoretical Problem in Empirical Research on Corporate Social Performance." The International Journal of Organizational Analysis 3229-67. 
Table 1

Descriptive information of sampled firms

\begin{tabular}{|c|c|c|}
\hline & No. of firms & \% of sample \\
\hline \multicolumn{3}{|l|}{ Location of the firm } \\
\hline North China & 34 & 41.0 \\
\hline South China & 25 & 30.1 \\
\hline East China & 5 & 6.0 \\
\hline West China & 19 & 22.9 \\
\hline \multicolumn{3}{|l|}{ Industrial Sector } \\
\hline Petrol and chemical & 11 & 13.3 \\
\hline Motor & 13 & 15.7 \\
\hline Electronic and optical & 10 & 12.0 \\
\hline Metal and machinery & 39 & 47.0 \\
\hline Construction & 5 & 6.0 \\
\hline Electricity and power & 3 & 3.6 \\
\hline Transportation and storage & 2 & 2.4 \\
\hline \multicolumn{3}{|l|}{ Firm Size } \\
\hline Large & 59 & 71.1 \\
\hline Medium \& small & 21 & 25.3 \\
\hline Small & 3 & 3.6 \\
\hline \multicolumn{3}{|l|}{ Ownership } \\
\hline State-owned & 70 & 84.3 \\
\hline Collective-owned & 3 & 3.6 \\
\hline Shareholding & 8 & 9.6 \\
\hline Private & 2 & 2.4 \\
\hline
\end{tabular}

Sources: Authors' calculations. 
Table 2

Perceptions of Socially Responsible Behaviour

\begin{tabular}{|c|c|c|c|c|c|c|}
\hline Statements & $N$ & 5 & 4 & 3 & 2 & 1 \\
\hline $\begin{array}{l}\text { 1. Complying with state law and being a good tax } \\
\text { payer (Government) }\end{array}$ & 83 & 72.3 & 25.3 & 2.4 & 0.0 & 0.0 \\
\hline $\begin{array}{l}\text { 2. Provision of quality products and services for } \\
\text { customers (Customers) }\end{array}$ & 83 & 67.5 & 26.5 & 6.0 & 0.0 & 0.0 \\
\hline $\begin{array}{l}\text { 3. Improving environmental quality and pollution } \\
\text { control (Environment) }\end{array}$ & 83 & 63.9 & 32.5 & 3.6 & 0.0 & 0.0 \\
\hline $\begin{array}{l}\text { 4. Provision of a healthy and safe working } \\
\text { environment (Employees) }\end{array}$ & 83 & 61.4 & 33.7 & 4.8 & 0.0 & 0.0 \\
\hline $\begin{array}{l}\text { 5. Creating value for company shareholders } \\
\text { (Shareholders) }\end{array}$ & 83 & 60.2 & 32.5 & 6.0 & 1.2 & 0.0 \\
\hline $\begin{array}{l}\text { 6. Doing business with its partners with integrity } \\
\text { (Business partners) }\end{array}$ & 83 & 45.8 & 48.2 & 6.0 & 0.0 & 0.0 \\
\hline $\begin{array}{l}\text { 7. Actively participating in social benefit activities } \\
\text { (Communities) }\end{array}$ & 83 & 24.1 & 59.0 & 15.7 & 1.2 & 0.0 \\
\hline
\end{tabular}

Note: $5=$ strongly agree, $4=$ agree, $3=$ neutral, $2=$ disagree, and $1=$ strongly disagree.

Sources: Authors' calculations. 
Table 3

CSR activities firms involved in the past three years

\begin{tabular}{ll|l|l}
\hline & & Total & $\%$ \\
\hline 1. & Organizing or participating in public welfare activities & 82 & 86.6 \\
2. & Encouraging employees' voluntary welfare programmes & 82 & 91.5 \\
3. Improving employee welfare (facilities and benefits) & 82 & 100.0 \\
4. Active contribution of tax to government & 82 & 97.6 \\
5. Improving pollution control/environment impact & 82 & 97.6 \\
6. Contribution to vulnerable group & 82 & 82.9 \\
7. Donation to charitable and public welfare organizations & 82 & 42.7 \\
8. Contribution to cultural and literary programmes & 82 & 62.2 \\
\hline
\end{tabular}

Sources: Authors' calculations. 
Table 4

Percentage of managers' response towards CSR by five scale (\%)

\begin{tabular}{|c|c|c|c|c|c|}
\hline Statements & 5 & 4 & 3 & 2 & 1 \\
\hline $\begin{array}{l}\text { 1. Engaging in socially responsible actions } \\
\text { does not comprimise the pursuit of profit }\end{array}$ & 27.7 & 30.1 & 9.6 & 28.9 & 3.6 \\
\hline $\begin{array}{l}\text { 2. To obtain a favourable public image can be } \\
\text { achieved by showing involved in socially } \\
\text { responsible activities. }\end{array}$ & 49.4 & 41.0 & 3.6 & 6.0 & 0.0 \\
\hline $\begin{array}{l}\text { 3. A socially responsible business could avoid } \\
\text { additional regulations imposed by the } \\
\text { government, and good relationship with the } \\
\text { government would gain firms more freedom } \\
\text { from all sorts of restrictions }\end{array}$ & 4.8 & 20.5 & 28.9 & 39.8 & 6.0 \\
\hline $\begin{array}{l}\text { 4. Contributing to community's program and } \\
\text { improve local development would bring in } \\
\text { firms' long run profitability }\end{array}$ & 22.9 & 49.4 & 18.1 & 8.4 & 1.2 \\
\hline $\begin{array}{l}\text { 5. Firms perceived as being socially } \\
\text { responsible can improve industry-labour } \\
\text { relations }\end{array}$ & 18.1 & 48.2 & 13.3 & 16.9 & 3.6 \\
\hline $\begin{array}{l}\text { 6. Socially responsible activities could } \\
\text { improve a firm's standing with banks; and } \\
\text { help them to gain easy access to bank loans }\end{array}$ & 3.6 & 36.1 & 30.1 & 26.5 & 3.6 \\
\hline $\begin{array}{l}\text { 7. Socially responsible activities could } \\
\text { improve a firm's standing with investors and } \\
\text { reduce financial risk }\end{array}$ & 6.0 & 36.1 & 32.5 & 20.5 & 4.8 \\
\hline $\begin{array}{l}\text { 8. Businesses have already had too much } \\
\text { burden over societal affaires and, they should } \\
\text { not get involved in more social activities. }\end{array}$ & 4.8 & 26.5 & 20.5 & 27.7 & 20.5 \\
\hline $\begin{array}{l}\text { 9. There is no difference between involvement } \\
\text { in socially responsible activities and } \\
\text { positioning for public relations. }\end{array}$ & 7.2 & 47.0 & 22.9 & 16.9 & 6.0 \\
\hline $\begin{array}{l}\text { 10. Too much social responsibility could } \\
\text { disadvantage firms economically. }\end{array}$ & 9.6 & 57.8 & 16.9 & 13.3 & 2.4 \\
\hline $\begin{array}{l}11 \text { Business would be more willing to take on } \\
\text { socially responsible activities when they are } \\
\text { economically more sustainable. }\end{array}$ & 2.4 & 6.0 & 10.8 & 45.8 & 34.9 \\
\hline
\end{tabular}

Sources: Authors' calculations. 
Table 5

Results of Factor Analysis for Attitudes towards CSR

\begin{tabular}{l|rrrrr}
\hline \multicolumn{1}{c|}{ Variable } & Facto1 & Factor 2 & Factor 3 & Factor 4 \\
\hline $\begin{array}{l}\text { 1. Engaging in socially responsible actions } \\
\text { does not comprimise the pursuit of profit. }\end{array}$ & .197 & .133 & .718 & -.015 \\
\hline 2. To obtain a favourable public image can & .412 & .595 & .043 & -.040
\end{tabular}

be achieved by showing involved in

socially responsible activities.

3. A socially responsible business could avoid additional regulations imposed by the government, and good relationship with the government would gain firms more freedom from all sorts of restrictions

4. Contributing to community's program and improve local development would bring in firms' long run profitability

5. Firms perceived as being socially responsible can improve industry-labour relations.

6. Socially responsible activities could improve a firm's standing with banks; and help them to gain easy access to bank loans

7. Socially responsible activities could improve a firm's standing with investors and reduce financial risk

8. Businesses have already had too much burden over societal affaires and, they should not get involved in more social activities

9. There is no difference between involvement in socially responsible activities and positioning for public relations

.196

.801

$-.006$

.113

10. Too much social responsibility could

.040

$-.047$

.818

.198

.401

$-.101$

$-.441$

disadvantage firms economically.

11. Business would be more willing to take

.024

$-.090$

$-.744$

.427 on socially responsible activities when they are economically more sustainable

Extraction Method: Principal Component Analysis. Rotation Method: Varimax with Kaiser Normalization.

Sources: Authors' calculations. 
Table 6

Statistical Description of Factor Analysis of Attitudes towards to CSR

\begin{tabular}{|c|c|c|c|}
\hline & $\begin{array}{l}\text { Factor } \\
\text { Loadings }\end{array}$ & Mean & Weighted Score \\
\hline $\begin{array}{l}\text { Factor 1- Firm with CSR can improve its } \\
\text { standing with Constituencies }\end{array}$ & & 3.29 & 2.46 \\
\hline $\begin{array}{l}\text { A socially responsible business could avoid } \\
\text { additional regulations imposed by the } \\
\text { government, and would gain firms more } \\
\text { freedom from all sorts of restrictions. }\end{array}$ & .750 & 3.59 & 2.69 \\
\hline $\begin{array}{l}\text { Socially responsible activities could improve a } \\
\text { firm's standing with banks; and help them to } \\
\text { gain easy access to bank loans. }\end{array}$ & .690 & 3.10 & 2.14 \\
\hline $\begin{array}{l}\text { Socially responsible activities could improve a } \\
\text { firm's standing with investors and reduce } \\
\text { financial risk. }\end{array}$ & .803 & 3.18 & 2.55 \\
\hline $\begin{array}{l}\text { Factor } 2 \text { - CSR produces better environment } \\
\text { for their business to grow }\end{array}$ & & 3.93 & 2.84 \\
\hline $\begin{array}{l}\text { To obtain a favourable public image will have } \\
\text { to show that it is socially responsible. }\end{array}$ & .595 & 4.34 & 2.58 \\
\hline $\begin{array}{l}\text { Contributing to community's program of } \\
\text { improving locals' quality of life would bring in } \\
\text { firms' long run profitability. }\end{array}$ & .801 & 3.84 & 3.08 \\
\hline $\begin{array}{l}\text { Firms perceived as being socially responsible } \\
\text { can encounter relatively low level of labour } \\
\text { problems. }\end{array}$ & .793 & 3.60 & 2.85 \\
\hline $\begin{array}{l}\text { Factor } 3 \text { - CSR and Economic Performance are } \\
\text { mutual benefit }\end{array}$ & & 2.72 & 1.98 \\
\hline $\begin{array}{l}\text { Engaging in socially responsible actions doesn't } \\
\text { conflict with pursuit of profit. }\end{array}$ & .718 & 3.49 & 2.51 \\
\hline $\begin{array}{l}\text { Business would be more willing to take on } \\
\text { socially responsible activities when they are } \\
\text { economically more sustainable. }\end{array}$ & .744 & 1.95 & 1.45 \\
\hline Factor 4 - CSR $=$ or $\neq$ Public Relations & & 3.33 & 2.72 \\
\hline $\begin{array}{l}\text { There is no difference between involvement in } \\
\text { socially responsible activities and positioning } \\
\text { for public relations. }\end{array}$ & .818 & 3.33 & 2.72 \\
\hline
\end{tabular}

Note: 1 = strongly disagree through 5 = strongly agree.

Sources: Authors' calculations. 
Table 7

Binary logit regressions on the determinants of CSR rating

\begin{tabular}{|l|l|l|}
\hline Independent variable: & $\begin{array}{l}\text { Model One } \\
\text { Odd ratio estimates }\end{array}$ & $\begin{array}{l}\text { Model Two } \\
\text { Odd ratio estimates } \\
(* \text { marginal effect })\end{array}$ \\
\hline Log (sale pre restructuring) & $0.28 \quad(3.12)^{*}$ & $0.28 \quad(3.12)$ \\
\hline Firms in State-ownership & $5.59 \quad(8.08) * * *$ & $5.50 \quad(7.80)$ \\
\hline Firms in high tech sector & $0.39(2.88) *$ & $0.40 \quad(2.54)$ \\
\hline Firms in North-west provinces & $1.93 \quad(1.16)$ & $1.96 \quad(1.18)$ \\
\hline Size of firms & $1.14 \quad(0.01)$ & $1.15 \quad(0.24)$ \\
\hline $\begin{array}{l}\text { Managers' education level above } \\
\text { university degree }\end{array}$ & $0.93 \quad(0.02)$ & $0.92 \quad(0.14)$ \\
\hline Mangers' age older than 56 years & 0.1738 & 83 \\
\hline Pseudo R square & 83 & 0.1573 \\
\hline Number of observations & & \\
\hline
\end{tabular}

Sources: Authors' calculations.

Notes:

(1) Dependent variable is 0 when sampled firms' CEOs is identified as against CSR; and is 1 when in favour of CSR. The models are estimated against the dependent variable when the value is zero.

(2) The natural probability of CSR decision is $41 \%$ (against CSR); and 59\% in favour of CSR.

(3) T-ratios are in brackets; $* * *$ denotes statistical significance at $1 \%$ and $*$ at $10 \%$ level.

(4) Omitted independent variables are firms not in state-ownership; firms in traditional sectors; firms are in south-east region; and small and medium sized firms. 
Table 8

OLS regressions on firms' performance with manager's rating towards corporate social responsibility (CRS)

\begin{tabular}{|l|l|l|}
\hline Independent variable: & \multicolumn{2}{l|}{ Dependent variable: Log (sales after restructuring) } \\
\hline Log (sale before restructuring) & & $0.8992(17.4)^{* * *}$ \\
\hline managers in favour of CSR & $0.9781(0.83)$ & $0.8610(1.65)^{*}$ \\
\hline $\begin{array}{l}\text { Firms in State-ownership (versus non-state } \\
\text { owned) }\end{array}$ & $0.7040(0.46)$ & $1.1293(1.64)^{*}$ \\
\hline $\begin{array}{l}\text { Firms in high tech sector (versus traditional } \\
\text { sectors) }\end{array}$ & $-1.4208(1.07)$ & $0.0133(0.02)$ \\
\hline $\begin{array}{l}\text { Firms in North-west provinces (versus } \\
\text { South-east provinces) }\end{array}$ & $3.1080(2.63) * * *$ & $0.6218(0.44)$ \\
\hline $\begin{array}{l}\text { Size of firms (large versus small and } \\
\text { medium firms) }\end{array}$ & $1.6315(1.31)$ & $0.2239(0.40)$ \\
\hline $\begin{array}{l}\text { Manages' educational level above } \\
\text { university degree }\end{array}$ & $2.0016(1.08)$ & $1.5500(1.87)^{*}$ \\
\hline Managers' age older than 56 years & $-1.9237(1.41)$ & $-1.0425(1.71)^{*}$ \\
\hline Intercept & $0.4340(0.22)$ & $-1.2938(1.47)$ \\
\hline $\begin{array}{l}\text { Dependent mean values (unite= log 10,000 } \\
\text { RMB yuan) }\end{array}$ & 4.138 & 4.138 \\
\hline F-statistics & 2.48 & 0.8234 \\
\hline $\begin{array}{l}\text { Adjusted R square } \\
\text { Number of observations }\end{array}$ & \\
\hline
\end{tabular}

Sources: Authors' calculations.

Notes

(1) T-ratios are in bracket;

(2) *** denotes statistical significance at $1 \%$ level; * at $10 \%$ level. 